УДК 577.1:612.015.11

\author{
І. Г. Сущенко ${ }^{2}$, О. М. Лещук ${ }^{1}$ I. В. Дрегваль ${ }^{1}$, А. І. Руденко ${ }^{2}$ \\ ${ }^{1}$ Дніпропетровський національний університет ім. Олеся Гончара \\ ${ }^{2}$ Інститут гастроентерології АМН України

\section{ЗМІНИ ПОКАЗНИКІВ РЕОГЕПАТОГРАМИ ПРИ ЗБІЛЬШЕННІ КОНЦЕНТРАЦЇ̈ NO В ОРГАНІЗМІ ЩУРІВ}

Визначено основні характеристики мікроциркуляторного русла печінки щурів при розвитку панкреатиту різного ступеня важкості за допомогою методу реографії, а також їх прогностичне значення. Підвищення вмісту NO в організмі тварин спричинюс виражене зменшення тонусу у великих судинах печінки. На судини середнього та малого діаметра підвищений вміст NO впливас менш виражено і нетривало. Використовуючи показники реогепатограм, можна визначити порушення гемодинаміки печінки та розпал хвороби - ішемії печінки, зниження опору артеріальних судин печінки, зменшення відтоку портальної крові на тлі гіпердинамічного типу кровообігу.

\author{
И. Г. Сущенко ${ }^{2}$, О. М. Лещук ${ }^{1}$, И. В. Дрегваль ${ }^{1}$, А. И. Руденко ${ }^{2}$ \\ ${ }^{1}$ Днепропетровский национальный университет им. Олеся Гончара \\ ${ }^{2}$ Институт гастроэнтерологии АМН Украины \\ ИЗМЕНЕНИЯ ПОКАЗАТЕЛЕЙ РЕОГЕПАТОГРАММЫ \\ ПРИ УВЕЛИЧЕНИИ КОНЦЕНТРАЦИИ NO В ОРГАНИЗМЕ КРЫС
}

\begin{abstract}
Определены основные характеристики микроциркуляторного русла печени крыс при развитии панкреатита разной степени тяжести с помощью метода реографии, а также их прогностическое значение. Повышение содержания NO в организме животных приводит к более выраженному уменьшению тонуса крупных сосудов печени, на сосуды среднего и малого диаметра влияние менее выражено и непродолжительно. Используя показатели реогепатограмм, можно определить нарушение гемодинамики печени при развитии болезней печени.
I. G. Sushchenko², O. M. Leshchuk' ${ }^{1}$ I. V. Dregval ${ }^{1}$, A. I. Rudenko²
${ }^{1}$ Oles’ Honchar Dnipropetrovsk National University
${ }^{2}$ Institute of Gastroenterology of NAMS of Ukraine

\section{CHANGES OF RHEOHEPATOGRAMME INDICES UNDER INCREASING NO CONCENTRATION IN RATS}

Basic descriptions of the rats liver microvasculature and its prognostic significance under development of pancreatitis of different severity were determined by a rheography method. Increased nitric monoxide content in the rats entails even more pronounced reduction of a tone of the liver's great vessels. The vessels of medium and small diameter are less influenced and the reduction was short-term. Using the rheohepatogramme indices makes possible to determine the disturbance of liver's haemodynamics under the hepatopathy development.
\end{abstract}




\section{Вступ}

Захворювання печінки - одне з найтяжчих, широко розповсюджених і складно діагностованих захворювань органів черевної порожнини. Його супроводжує ряд ускладнень, а клінічний перебіг і результат захворювання часто важко передбачувані. При важких панкреатитах насамперед страждають мікроциркуляція та системна гемодинаміка [2]. Актуальною залишається проблема прогнозування потенційної ваги гострого панкреатиту, можливості передбачити деструктивний процес на початку захворювання. Наявність періоду оборотних патологічних змін (ішемії та некробіозу) у перебігу гострого деструктивного панкреатиту дозволяє проводити терапію захворювання [1; 3; 5]. Однією 3 можливостей поліпшити стан при розвитку захворювання $€$ збільшення мікроциркуляції крові у печінці.

Мікрогемодинаміка печінки може змінюватись залежно від концентрації NO в організмі. Оксид азот - один із найважливіших біологічних медіаторів, залучений у безліч фізіологічних і патофізіологічних процесів. Характерна риса NO - його здатність швидко активувати одні ензими усередині клітини та інгібувати інші. $N O €$ вазодилататорною молекулою, що змінює тонус у деяких судинних басейнах [14], включаючи легені та системний кровообіг [16]. Ця молекула утворюється переважно 3 індуцибельної (iNOS) та ендотеліальної (eNOS) синтаз оксиду азоту у печінці [15], зокрема оксид азоту, що синтезується за допомогою eNOS - важливий фактор регуляції нормального печінкового кровотоку. $L$-аргінін - субстрат для всіх ізоформ NOS при продукуванні $N O$ [11]. Оксид азоту ефективно полегшує портальну гіпертензію при цирозах печінки [12]. Він також бере участь у реалізації багатьох важливих фізіологічних функцій, таких як вазодилатація, регуляція тонусу гладеньких м'язів, нейротрансмісія тощо [4; 7;9].

Вплив NO вивчається за допомогою експериментальних моделей захворювань печінки. На сьогодні існують моделі патології, які індукуються нітро- $L$-аргініном, тетрахлоркарбоном $\left(\mathrm{CCl}_{4}\right)$, етанолом $\left(\mathrm{C}_{2} \mathrm{H}_{5} \mathrm{OH}\right)$, нітропурсидом натрію. Викликаючи певні розлади у системі внутрішньопечінкового кровообігу, виникає проблема реєстрації зміни кровонаповнення. Сучасні методи функціональної діагностики розладів периферичного кровообігу мають різні діагностичні можливості [10; 13; 17].

Для визначення змін кровообігу в експериментальних умовах нами уперше запропоновано реографічний метод реєстрації показників мікроциркуляції крові у печінці в експериментальних умовах на дрібних лабораторних тваринах.

Метод реографії дозволяє оцінювати загальні та регіональні зміни у судинній системі печінки, викликані функціональними судинними розладами. В основі методу реографії лежить принцип реєстрації мінливих у часі коливань електричного опору судинної системи печінки. Ці зміни електричного опору відбуваються у ритмі скорочення серця та залежать від змін обсягу крові, що протікає у судинній системи печінки. Метод реографії належить до неінвазивних методів дослідження кровообігу у печінці, що дозволяє побічно судити про кровонаповнення різних відділів судинної системи, тонус та еластичність судин, стан судинної стінки при різних патологіях (судинної недостатності, спазмі). Дана методика безпечна, проста у використанні та аналізі отриманих результатів, досить інформативна, а також може за необхідності застосовуватися багаторазово на одній тварині. Повторні дослідження на тій самій тварині дозволяють порівнювати різні реографічні криві та цим самим спостерігати за динамікою гемодинамічних змін. 
Тому завдання нашого дослідження полягало у визначенні основних характеристик мікроциркуляторного русла при розвитку панкреатиту різного ступеня важкості за допомогою методу реографії, а також його прогностичного значення. Зважаючи на те, що гемодинамічне порушення з'являється вже на ранніх стадіях захворювання [18] i характеризується зростанням загального судинного опору, зниженням обсягу циркулюючої крові, зменшенням центрального венозного тиску та порушеннями мікроциркуляції, ми провели дослідження зі зниження загального опору судин та, як наслідок, підвищення мікроциркуляції крові у печінці.

\section{Матеріал і методи досліджень}

Дослідження проведено на 10 білих щурах-самцях масою 180-240 г віком 6 місяців. Усі тварини утримувались в однакових умовах. Тварин поділили на три групи. Першу групу склали інтактні тварини, другу - тварини, яким одноразово вводили нітропрусид натрію (1,5 мг/кг маси тіла), до третьої увійшли тварини після тривалого (6-деннного) уведення нітропрусиду натрію (1,5 мг/кг маси тіла). За 16-20 годин до експериментів тварин піддавали харчовій депривації при вільному доступі до води.

Реєстрацію реограми печінки щурів здійснювали за допомогою поліграфа П6Ч-01 із комп'ютерною обробкою результатів дослідження. Методика реографії [4; 9] в наших експериментах була дещо видозмінена у зв'язку з тим, що реогепатограма (РГГ) щурів ще ніколи не мала місця у науковій практиці. Реєстрація РГГ у щурів відрізняється від методики реографії, яку використовують при записі РГГ людини, вона проводиться під наркозом.

У наших експериментах тварини черевом догори у стані наркозу були закріплені на спеціальних дошках за допомогою марлевих фіксаторів. До кінцівок тварини приєднували електроди для реєстрації електрокардіограми (ЕКГ, друге відведення) та реограми печінки. Для реєстрації РГГ використовували два електроди: великий, що являє собою прямокутну мідну пластинку $(6$ × 10 см), та маленький біполярний $(1,5 \times 3$ см). Для підвищення електропровідності та зменшення опору між електродами та шкірою тварин використано прокладку, змочену фізіологічним розчином.

Великий електрод (індиферентний) розміщувався на середині спини лабораторного щура (вигін хребта) в області розташування печінки, менший (активний) - на центрі грудної клітки та під правим реберним краєм тварини.

Запис РГГ проводили синхронно з ЕКГ. Під час аналізу отриманих реограм вивчали форму вершини основної хвилі, кількість і виразність додаткових зубців, а також кількісно визначали час поширення пульсової хвилі, кут нахилу анакроти, тривалість висхідної та спадної частин пульсової хвилі, їх співвідношення та амплітуди. За літературними даними [8], у нормі вершина реограми повинна бути гострою, без додаткових зубців, а інцизура та дикротичний зубець чітко виражені.

Найважливіші параметри РГГ, які підлягали аналізу в наших експериментах:

- Qx - відображає час асинхронного та ізометричного скорочення шлуночків, вимірюється від початку зубця Q на ЕКГ до початку РГГ. Цей показник характеризує швидкість розповсюдження пульсової хвилі на ділянці «серце - судини» печінки;

- a - тривалість систолічної хвилі (c) від початку підйому реограми до інцизури. Характеризує час артеріального наповнення печінки у фазу швидкого та повільного наповнення печінкової артерії та їі гілок;

- b - тривалість постсистолічної хвилі (с) від інцизури до з'єднання кривої 3 ізолінією. Характеризує час кровонаповнення басейну ворітної вени; 
- a/b - змінюється при порушенні кровонаповнення артеріального або портального бассейну;

- $\alpha / \beta-$ відношення тривалості підйому систолічної хвилі (період максимального наповнення) до тривалості спуску всієї хвилі (тривалість катакроти). Характеризує тонус судин та їх еластичність;

- $\mathrm{h}_{1} / \mathrm{h}_{2}$ - частка від поділу амплітуди систолічної хвилі на амплітуду постсистолічної хвилі (співвідношення артеріального кровотоку до венозного);

- PI - реографічний індекс - співвідношення амплітуди систолічної хвилі до каліброваного імпульсу. Характеризує величину систолічного припливу;

- АЧП - амплітудно-частотний показник. Характеризує інтенсивність кровообігу у мікроциркуляторному руслі.

Статистичну обробку отриманих даних проводили за допомогою комп'ютерних програм із використанням методів варіаційної статистики [6; 8]. При цьому для показника визначали середне арифметичне значення $(M)$ та похибку середнього $(m)$. Досліджувані співвідношення вважали достовірними при $p<0,05$.

\section{Результати та їх обговорення}

На першому етапі наших досліджень установлено, що при одноразовому уведенні нітропрусиду натрію на РГГ спостерігалось збільшення артеріального припливу (показник (а) табл. 1), що ймовірно $є$ наслідком зниження пульсових коливань артеріальних печінкових судин. Це підтверджується даними реограм (час максимального підйому на реограмі). Артеріальне наповнення печінки у фазі швидкого та повільного наповнення печінкової артерії та іiі гілок відбувалося за 10 та 20 хв відповідно (рис. 1).

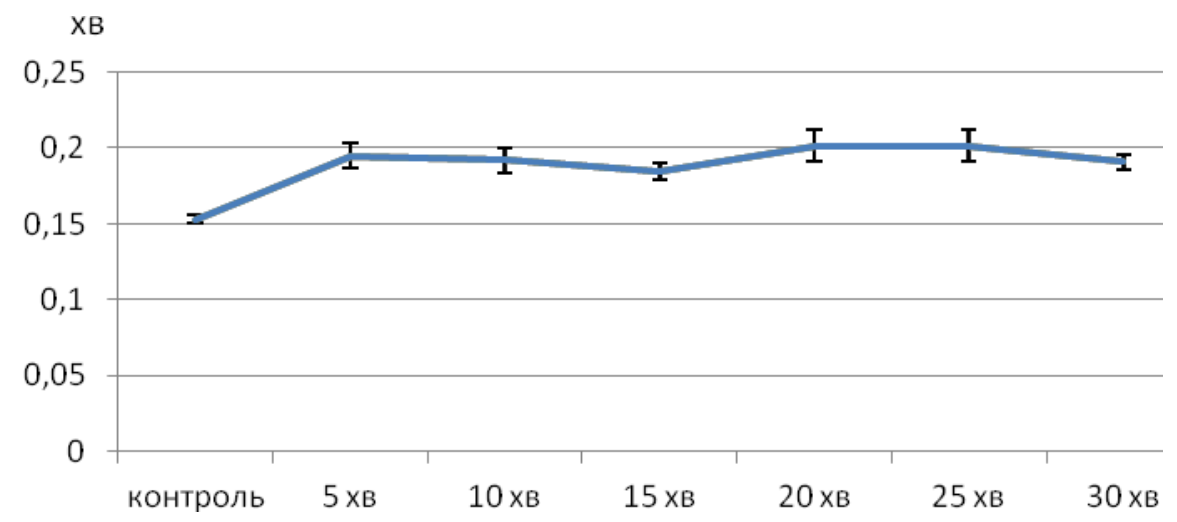

Рис. 1. Динаміка тривалості артеріального наповнення печінки щурів після уведення нітропрусиду натрію: на осі абсцис - час замірів тривалості постсистолічної хвилі реогепатограм щурів; на осі ординат - час тривалості постсистолічної хвилі реогепатограм щурів після уведення нітропрусиду натрію

Найбільший ефект зменшення портального кровотоку у наших дослідженнях спостерігався через 15 хв після уведення препарату нітропрусид натрію в організм щурів. Незважаючи на зменшення портального кровотоку печінки в 2,5 раза порівняно 3 контролем (показник $(\mathrm{a} / \mathrm{b})$ табл. 1), збільшення тривалості діастолічної хвилі (показник (b) табл. 1) на реограмі, ймовірно, свідчить про застій у портальній системі печінки, що може бути розвитком тенденції до збільшення загального судинного опору печінки.

Уведення нітропрусиду натрію викликає зменшення тонусу великих судин i збільшення наповнення печінки. За даними наших досліджень, на судини середнього 92 
та малого радіусу уведення нітропрусиду натрію впливає не так істотно, як на судини великого радіусу (рис. 2, 3). Відтік крові від печінки дещо зменшується відносно ії притоку. Це викликає збільшення печінки у розмірі та деякий застій крові. Найбільший ефект спостерігається на 15-й хв після уведення нітропрусиду натрію, потім його дія дещо слабшає, але до контрольних величин діаметр великих судин не доходить. Ефект зменшення тонусу судин можна простежити за показником $(\alpha / \beta)$ (див. табл. 1$)$.

На 25-й хв спостерігалось збільшення відтоку крові, що ймовірно $є$ впливом нітропрусиду натрію на судини середнього та малого діаметра, але вже на 30-й хв цей вплив зменшується. За даними наших експериментів, після уведення препарату спостерігалось збільшення тривалості постсистолічної хвилі з піком на 20-й хв експерименту (див. рис. 2).

Таблиия 1

Показники реогепатограм щурів до та після уведення нітропрусиду натрію

\begin{tabular}{|c|c|c|c|c|c|c|c|c|}
\hline \multicolumn{2}{|c|}{$\begin{array}{c}\text { Показники } \\
\text { реограми }\end{array}$} & контроль & 5 хв & 10 хв & 15 хв & 20 хв & 25 хв & 30 хв \\
\hline \multirow{2}{*}{$\mathrm{Qx}$} & $M$ & 0,021 & 0,015 & 0,019 & 0,019 & 0,020 & 0,020 & 0,024 \\
\cline { 2 - 9 } & $m$ & 0,002 & 0,002 & 0,002 & 0,002 & 0,002 & 0,002 & 0,006 \\
\hline \multirow{2}{*}{$\mathrm{a}$} & $M$ & 0,153 & 0,195 & 0,192 & 0,185 & 0,201 & 0,201 & 0,191 \\
\cline { 2 - 9 } & $m$ & 0,003 & 0,009 & 0,008 & 0,005 & 0,010 & 0,010 & 0,005 \\
\hline \multirow{2}{*}{$\mathrm{b}$} & $M$ & 0,323 & 0,326 & 0,329 & 0,330 & 0,350 & 0,350 & 0,313 \\
\cline { 2 - 9 } & $m$ & 0,009 & 0,013 & 0,011 & 0,015 & 0,015 & 0,010 & 0,014 \\
\hline \multirow{2}{*}{$\mathrm{a} / \mathrm{b}$} & $M$ & 0,490 & 0,645 & 0,614 & 1,290 & 0,598 & 0,680 & 0,639 \\
\cline { 2 - 9 } & $m$ & 0,015 & 0,038 & 0,024 & 0,064 & 0,026 & 0,029 & 0,063 \\
\hline \multirow{2}{*}{$\alpha / \beta$} & $M$ & 1,540 & 1,189 & 0,576 & 0,554 & 1,151 & 1,272 & 1,097 \\
\cline { 2 - 9 } & $m$ & 0,067 & 0,080 & 0,015 & 0,018 & 0,064 & 0,097 & 0,071 \\
\hline \multirow{2}{*}{$\mathrm{h}_{1} / \mathrm{h}_{2}$} & $M$ & 0,565 & 0,567 & 0,576 & 0,554 & 0,531 & 0,521 & 0,561 \\
\cline { 2 - 9 } & $m$ & 0,017 & 0,026 & 0,015 & 0,018 & 0,021 & 0,023 & 0,027 \\
\hline \multirow{2}{*}{$\mathrm{RI}$} & $M$ & 1,496 & 1,453 & 1,431 & 1,431 & 1,414 & 1,396 & 1,335 \\
\cline { 2 - 9 } & $m$ & 0,024 & 0,023 & 0,018 & 0,018 & 0,017 & 0,014 & 0,023 \\
\hline \multirow{2}{*}{$\mathrm{AЧП}$} & $M$ & 3,020 & 2,958 & 2,784 & 2,927 & 2,717 & 2,946 & 2,768 \\
\cline { 2 - 8 } & $m$ & 0,079 & 0,161 & 0,112 & 0,134 & 0,148 & 0,131 & 0,112 \\
\hline
\end{tabular}

Збільшення тривалості постсистолічної хвилі, можливо, пов'язане 3 повільним впливом нітропрусиду натрію на судини середнього та малого діаметра, що відображається у мікроциркуляції крові у печінці. Тільки через 30 хв після уведення препарату спостерігалось збільшення мікрогемодинаміки печінки, що, можливо, пов' язано, з одного боку, з дією лікарського засобу на судини середнього та малого діаметра, 3 іншого - iз припиненням дії нітропрусиду натрію на судини великого діаметра (показник ( $\alpha / \beta)$ табл. 1). 


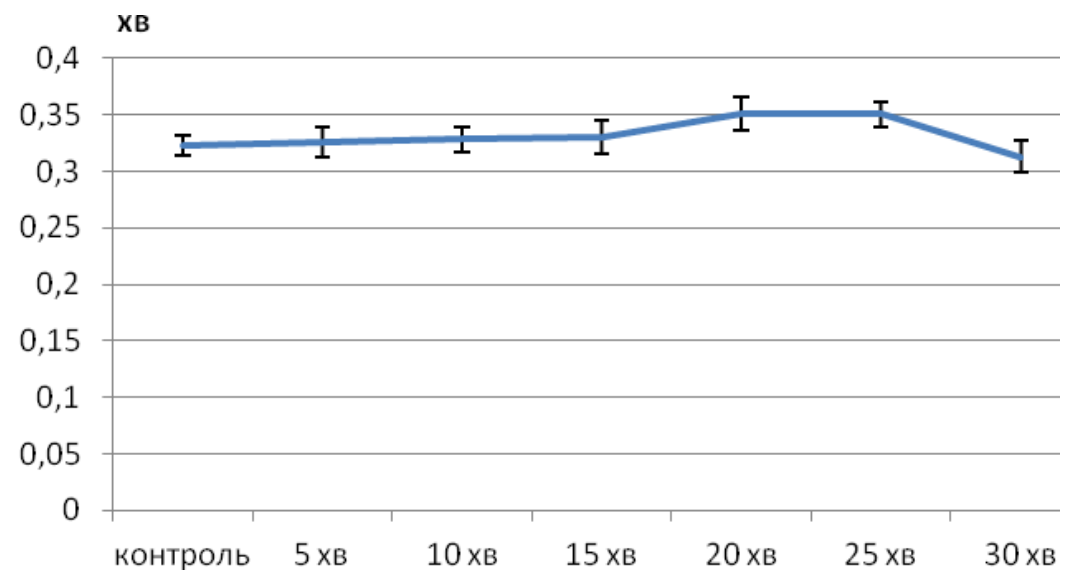

Рис. 2. Динаміка тривалості постсистолічної хвилі реогепатограм щурів після уведення нітропрусиду натрію: показники ті самі, що і на рис. 1

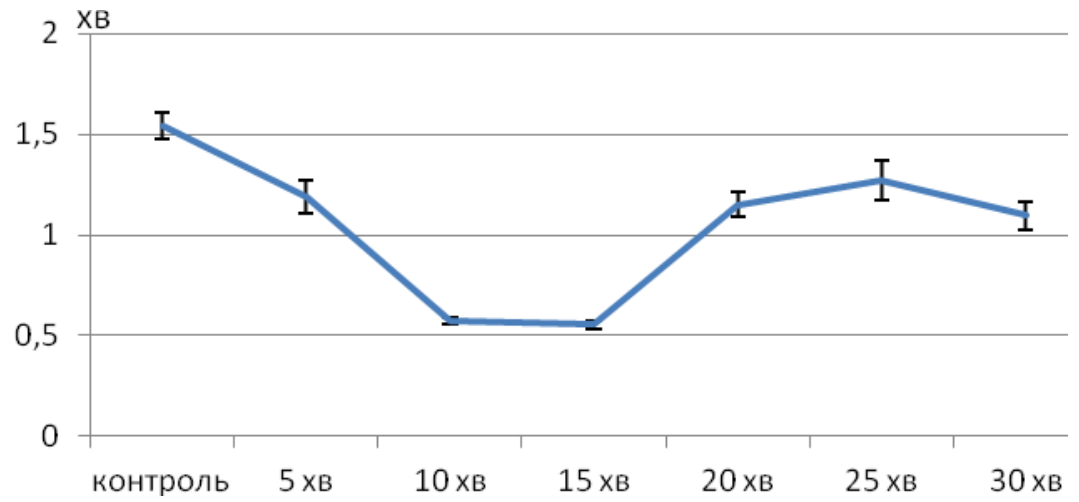

Рис. 3. Динаміка відношення тривалості систолічної та діастолічної хвилі реограми печінки щурів після уведення нітропрусиду натрію: показники ті самі, що і на рис. 1

Враховуючи будову печінки щура, котра складається 3 п'яти частин, до яких кров потрапляє двома шляхами: від ворітної вени та печінкової артерії, після уведення препарату амплітуда систолічної хвилі дещо знижується, але тривалість підвищується у зв'язку з наповненням чисельних гілок і синусів печінки. Збільшення тривалості кровонаповнення судин печінки також пов'язане зі зниженням тиску крові як одного 3 факторів дії нітропрусиду натрію на судинну систему щурів.

Характеризуючи тонус судин та їх еластичність, можна відзначити, що найбільше зменшення тонусу судин спостерігалось на 15-й хв після уведення нітропрусиду натрію в організм щурів (див. рис. 3). Подальше збільшення тривалості кровообігу у мікроциркулярному руслі печінки щурів пов'язане із загальним зниженням тонусу судин та тиску крові за дії препарату. Величина об’ємного кровотоку після введення нітропрусиду натрію дещо зменшується 3 піком на 20-й хв, але протягом досліджень вона мала більш або менш стабільні коливання (див. табл. 1).

\section{Висновки}

Підвищення вмісту оксиду азоту в організмі тварин викликає виражене зменшення тонусу великих судин печінки. На судини середнього та малого діаметра вплив 
підвищеного вмісту оксиду азоту менш виражений і нетривалий. Підвищений вміст оксиду азоту може викликати деякий застій крові у печінці, що імовірно $є$ одним із факторів розвитку панкреатиту. Використовуючи показники реогепатограм, можна визначити порушення гемодинаміки печінки та розпал хвороби - ішемії печінки, зниження опору артеріальних судин печінки, зменшення відтоку портальної крові на фоні гіпердинамічного типу кровообігу (збільшення серцевого викиду та зниження загального периферичного опору).

\section{Бібліографічні посилання}

1. Вострокнутов И. В. Хирургическое лечение больных острым билиогенным панкреатитом: Автореф. дисс. ... канд. мед. наук. - Новосибирск: Новосиб. гос. мед. акад, 2004. - 21 с.

2. Кровотечение и трансфузиология / Ю. С. Винник, Л. В. Кочетова, Е. А. Карлова, С. С. Дунаевская. - М. : Феникс, 2007. - 160 с.

3. Кондратенко П. Г. Острый панкреатит / П. Г. Кондратенко, А. А. Васильев, М. В. Конькова. Донецк, 2008. -352 с.

4. Логинов А. С. Реограмма печени в норме и патологии / А. С. Логинов, Ю. Т. Пушкарь // Терапевтический архив. -1962 . - № 3. - С. 81-83.

5. Метод лапароскопически ассоциированной операции при деструктивном панкреатите / Э. Г. Абдуллаев, Г. В. Ходос, В. В. Бабышин и др. // Эндоскоп. хирургия. - 2003. - Т. 9, № 5. - С. 58-59.

6. Петри А. Наглядная статистика в медицине / А. Петри, К. Сэбин. - М. : Геотар-мед, 2003. $143 \mathrm{c}$.

7. Полищук В. И. Техника и методика реографии и реоплетизмографии / В. И. Полищук, Л. Г. Терехова. - М. : Медицина, 1983. - 175 с.

8. Справочник по дифференциальной диагностике внутренних болезней / Под ред. Г. П. Матвейкова. - Минск : Беларусь, 1990. - 607 с.

9. Таджиев К. Т. Изменение реограммы печени при различных заболеваниях // Советская медицина. - 1967. - № 2. - С. 13-16.

10. Boros M. Methods for in vivo investigation of human microcirculation // Orv. Hetil. - 2001. Vol. 142 (21). - P. 1111-1114.

11. Bruckdorfer R. The basics about nitric oxide // Mol. Aspects Med. - 2005. - Vol. 26. - P. 3-31.

12. Differential expression and localization of nitric oxide synthases in cirrhotic livers of bile ductlegated rats / C. L. Wei, H. E. Khoo, K. H. Lee, W. M. Hon // Nitric Oxide. - 2002. - N 7. - P. 91-102.

13. Hwang T. L. The changes of hepatic sinusoidal microcirculation and effects of nitric oxide synthase inhibitor during sepsis / T. L. Hwang, M. L. Han // Hepatogastroenterology. - 2003. - Vol. 50 (49). P. 213-216.

14. Management of cirrhosis and ascites / P. Gines, A. Cardenas, V. Arroyo, J. Rodes // N. Engl. J. Med. 2004. - Vol. 350. - P. 1646-1654.

15. Marletta M. A. Catalysis by nitric oxide synthase / M. A. Marletta, A. R. Hurshman, K. M. Rusche // Curr. Opin. Chem. Diol. - 1998. - Vol. 2. - P. 656-663.

16. Nitric oxide modulates hepatic vascular tone in normal rat liver / M. K. Mittal, T. K. Gupta, F. Y. Lee et al. // Am. J. Physiol. - 1994. - Vol. 267. - P. G416-G422.

17. Tawadrous M. N. Persistence of impaired hepatic microcirculation after non arterialized liver transplantation in the rat / M. N. Tawadrous, A. Zimmermann, X. Y. Zhang // Microcirculation. 2002. - Vol. 9, N 5. - P. 363-375.

18. The course of bacterial infection of the pancreas and its relation to disease severity in rodent model of acute necrotizing pancreatitis / T. Foitzik, K. Mithofer, M. J. Ferraro et al. // Ann. Surg. - 1999. Vol. 220. - P. 193-198.

Надійшла до редколегії 02.08.2012 